\title{
Biochemical and muscle studies in patients with acute onset post-viral fatigue syndrome
}

\author{
V R Preedy, D G Smith, J R Salisbury, T J Peters
}

\begin{abstract}
Aims-To investigate in detail various biochemical and pathophysiological indices of muscle pathology in acute onset post-viral fatigue syndrome (PVFS).

Methods-Twenty three patients with PVFS (of mean duration $4 \cdot 6$ years) were subjected to needle biopsy for histomorphometry and total RNA contents. Plasma analysis included serology and creatine kinase activities. Indices of whole body mass were also measurednamely, whole body potassium content and plasma carnosinase activities.

Results-About $80 \%$ of the patients had serology indicative of persistent enteroviral infection as determined by VP1 antigen assay. Only about $10 \%$ of that same group of patients had serological indications of current enterovirus infection by IgM assay; a separate subset of $10 \%$ showed antibody changes suggestive of reactivation of Epstein-Barr virus. Quantitative morphometric analysis of skeletal muscle fibres indicated that the quadriceps muscle was normal or displayed only minor abnormalities in 22 patients. The Quetelet's Index (body mass index) and whole-body potassium values (index of lean body mass) were not affected in PVFS. The mean plasma carnosinase and creatinine kinase activities were also generally normal in these patients. The mean muscle RNA composition-mg RNA/mg DNA-was significantly reduced in acute onset PVFS by about $15 \%$. The protein:DNA ratio was not significantly affected.

Conclusions-Patients with acute onset PVFS, therefore, lose muscle protein synthetic potential, but not muscle bulk. Histopathology is consistent with these observations. These perturbations may contribute to the apparent feature of perceived muscle weakness associated with the persistent viral infection in the muscle themselves.
\end{abstract}

( Clin Pathol 1993;46:722-726)

Patients with acute onset post-viral fatigue syndrome (PVFS), also known as myalgic encephalomyelitis, ${ }^{1}$ always complain of muscle fatigue, which is exacerbated by physical or mental activity, or both. ${ }^{1-3}$ This contrasts with the normal physiological behaviour of their muscles shown in controlled tests of power and fatigue. ${ }^{23}$ Other investigations of muscle, however, have shown subtle abnormalities in patients with myalgic encephalomyelitis, ${ }^{4-7}$ and these might have profound physiological implications. Widely scattered necrotic muscle fibres without an inflammatory infiltrate have been reported in two patients. ${ }^{4}$ Further abnormalities supporting a diagnosis of peripheral disease include single fibre electromyography, which has been reported to show "jitter" in $75 \%$ of cases but without impulse blocking. Standard electromyography has shown no specific abnormality. ${ }^{6}$ Increased intracellular acidosis during exercise has also been documented in one patient with myalgic encephalomyelitis. ${ }^{7}$ There seems, therefore, to be contrasting evidence for peripheral muscle pathology.

\section{Methods}

Twenty three women (aged 20-65 years) were selected for study on the basis of a history typical of acute onset post-viral fatigue syndrome, as defined by Smith. ${ }^{1}$ Their symptoms had been preceded by a history of a "flu"-like illness and had been either relapsing, remitting, or chronic in nature. Their main symptoms were of muscular fatigue associated with discomfort after exercise, lethargy, lack of concentration and short-term memory dysfunction and were associated with many other lesser symptoms. ${ }^{1}$ The duration of symptoms varied from six months to 17 years. These patients had no significant medical or psychiatric history and had been fit and well until the onset of this new disease process. All had had a normal physical examination.

All patients had assays for full blood count, erythrocyte sedimentation rate, white cell differential, and white cell subset assays, a rheumatoid antibody haemagglutination assay, 10 channel SMAC, including estimation of serum glucose and thyroid stimulating hormone. Patients also had viral and antinuclear antibody screens. Similar biochemical data were also obtained from control female patients who attended elective surgery or outpatient clinics for non-specific complaints other than PVFS.

\section{STUDIES ON MUSCLES}

Muscle biopsy specimens were taken from the vastus lateralis portion of the quadriceps muscle with a UCH biopsy needle under local anaesthesia, as described by Edwards et al. ${ }^{8}$ 
Table 1 Muscle fibre morphometry in PVFS

\begin{tabular}{|c|c|c|c|c|c|c|}
\hline \multirow[b]{3}{*}{$\begin{array}{l}\text { Case } \\
\text { Number }\end{array}$} & \multicolumn{3}{|c|}{ Type I muscle fibres } & \multicolumn{3}{|c|}{ Type II muscle fibres } \\
\hline & Mean & Atrophy & Hypertrophy & Mean & Atrophy & Hypertrophy \\
\hline & $\begin{array}{l}\text { Fibre } \\
\text { diameter }\end{array}$ & $\begin{array}{l}\text { Factor } \\
(N R<400)\end{array}$ & $\begin{array}{l}\text { Factor } \\
(N R<400)\end{array}$ & $\begin{array}{l}\text { Fibre } \\
\text { diameter }\end{array}$ & $\begin{array}{l}\text { Factor } \\
(N R<200)\end{array}$ & $\begin{array}{l}\text { Factor } \\
(N R<180)\end{array}$ \\
\hline 1 & $58 \cdot 6$ & 0 & 214 & 45.4 & 52 & 26 \\
\hline 2 & $62 \cdot 1$ & 0 & 333 & $50 \cdot 2$ & 37 & 54 \\
\hline 3 & 54.5 & 0 & 343 & 53.9 & 0 & 138 \\
\hline 4 & 51.9 & 0 & 37 & $48 \cdot 7$ & 15 & 7 \\
\hline $5^{\star}$ & 57 & 0 & 109 & 36.9 & $280 \ddagger$ & 0 \\
\hline 6 & $54 \cdot 1$ & 33 & 100 & 53.5 & 0 & 23 \\
\hline $7^{\star}$ & 65.9 & 0 & $526 \dagger$ & $58 \cdot 2$ & 61 & $265 \dagger$ \\
\hline $8^{\star}$ & 47.9 & 27 & 75 & $28 \cdot 7$ & $779 \ddagger$ & 0 \\
\hline 9 & $60 \cdot 4$ & 0 & 171 & $49 \cdot 5$ & $23^{+}$ & 0 \\
\hline 10 & $45 \cdot 2$ & 11 & 5 & $40 \cdot 3$ & 104 & 0 \\
\hline 11 & 50.9 & 11 & 23 & $42 \cdot 2$ & 25 & 62 \\
\hline 12 & 53.7 & 0 & 10 & $47 \cdot 3$ & 7 & 7 \\
\hline 13 & 58.5 & 0 & 150 & $47 \cdot 4$ & 37 & 18 \\
\hline 14 & $52 \cdot 3$ & 0 & 27 & $42 \cdot 3$ & 48 & 0 \\
\hline $15^{\star}$ & $71 \cdot 7$ & 0 & $1011 \dagger$ & 62.9 & 0 & $282 \dagger$ \\
\hline $16^{\star}$ & $67 \cdot 7$ & 0 & $792 \dagger$ & $52 \cdot 1$ & 35 & $223 \dagger$ \\
\hline 17 & $48 \cdot 8$ & 25 & 23 & $45 \cdot 0$ & 50 & $25^{\circ}$ \\
\hline $18^{\star}$ & $62 \cdot 7$ & 0 & $419 \dagger$ & $44 \cdot 5$ & 113 & 0 \\
\hline 19 & 65.9 & 0 & 363 & $45 \cdot 1$ & 42 & 0 \\
\hline $20^{\star}$ & $54 \cdot 6$ & 20 & 290 & $60 \cdot 5$ & 0 & $326 \dagger$ \\
\hline $21^{\star}$ & $45 \cdot 1$ & 0 & 0 & 42.9 & $230 \ddagger$ & 38 \\
\hline 22 & 54.9 & 0 & 25 & $45 \cdot 1$ & 61 & 0 \\
\hline 23 & $60 \cdot 5$ & 0 & 337 & $39 \cdot 3$ & 0 & 31 \\
\hline (23) & $56.6(1.5)$ & $6(2)$ & $234(55)$ & $47 \cdot 0(1 \cdot 6)$ & $87(35)$ & $66(22)$ \\
\hline
\end{tabular}

*identifies those patients with abnormal muscle fibre morphometry. $\dagger=$ hypertrophy, $\ddagger=$ atrophy. Normal ranges (NR) are indicated in parentheses.

Each biopsy specimen was separated into two parts. One part was immediately blotted and stored at $-70^{\circ} \mathrm{C}$ for subsequent RNA and DNA estimation (see below): the other was snap-frozen for histopathological examination. Frozen sections $(6 \mu \mathrm{m})$ were stained with haematoxolin and eosin, periodic acid Schiff with and without diastase, oil-red $\mathrm{O}$, $\mathrm{NADH}$ and myosin $\mathrm{Mg}^{2+}$ adenosine triphosphatase (ATPase). ${ }^{9}$ Using the ATPase sections, fibres numbers and fibre diameters for type I and type II fibres were estimated on a Magiscan image analysis system, using an interactive computer program..$^{10}$ Atrophy and hypertrophy factors were then calculated, as described before. ${ }^{11}$ The normal values have been described in previous publications ${ }^{910}$ and are also set out in table 1 .

Protein RNA and DNA were measured by the spectrometric and fluorometric techniques, described by Preedy and Peters. ${ }^{12}$ Processing of muscle was carried out at $0-4^{\circ} \mathrm{C}$, unless otherwise stated. Skeletal muscle biopsy specimens were homogenised in 2 $\mathrm{ml}$ distilled water, using an ultrasonic tissue homogeniser with a micro-probe (Northern Media Supply Company, Hull, England). Homogenates were then acid precipitated in $0.2 \mathrm{~mol} / \mathrm{l}$ perchloric acid and centrifuged $(2000 \times g$ for 20 minutes). The supernatant fluid was discarded and the pellet suspended in $2 \mathrm{ml}$ of $0.2 \mathrm{~mol} / 1$ perchloric acid, mixed vigorously, and re-centrifuged $(2000 \times \mathrm{g}$, for 20 minutes). The supernatant fluid was again discarded and the pellet suspended in $2 \mathrm{ml}$ $0.3 \mathrm{~mol} / 1 \mathrm{NaOH}$ for 1 hour. This was acidprecipitated with $0.5 \mathrm{ml}, 2 \mathrm{~mol} / 1$ perchloric acid and centrifuged $(2000 \times g$ for $20 \mathrm{~min}$ utes). The supernatant fluid was used to determine RNA by the dual wavelength method-at $260 \mathrm{~nm}$ and $232 \mathrm{~nm}$, as described by Munro and Fleck. ${ }^{13}$ Protein was estimated as a modification of the methods described by Lowry et $a l^{14}$ and Downs and Wilfinger (for DNA). ${ }^{15}$

\section{WHOLE BODY POTASSIUM}

Measurements of total body potassium were carried out to assess lean body mass, as described by Smith et al. ${ }^{16}$ Patients were laid supine in an $\mathrm{NaI}$ whole-body counter with an array of eight detectors, data from which were analysed by a 512 -channel analyser. Counting was done for 3.3 hours and appropriate corrections were made for backgrounds. As lean body mass varies with age, sex, and height, patient data cannot be reliably presented as absolute values, but instead are compared with age, sex, and height matched controlsthat is, as a percentage. ${ }^{16}$

\section{SEROLOGY}

Serum was assayed for VP1 polypeptide, using an enterovirus group specific monoclonal antibody (5-D8/1), as described by Yousef et al. ${ }^{17}$ The assay used the specific antibody 5-D8/1 which acts against a single enterovirus capsid protein-virus protein 1 (VP1). The antibody does not generally react with non-enteroviral proteins. ${ }^{17}$ Enterovirus group specific IgM antibodies were assayed using the method of McCartney et al. ${ }^{18}$ Assays to assess reactivation of Epstein-Barr virus antibody were done according to the method of Hotchin et al. ${ }^{9}$

\section{SERUM ENZYMES}

Serum carnosinase was determined by the fluorometric method, described by Duane and Peters. ${ }^{20}$ Creatine kinase activities were assayed by routine clinical laboratory procedures.

\section{STATISTICS}

All data were the mean (SEM) ( $n-1$ weighing) of five to 23 subjects in each group. Differences between means were assessed by Student's $t$ test where variances were equal and when data were normally distributed. Data not normally distributed were analysed using the Wilcoxon rank sum test, as indicated in the relevant text. Statistical tests were performed using the package, Routine Statistics, version 6.3 (RS Cormack and GD Smith, Northwick Park Hospital and Clinical Research Centre, Harrow, Middlesex, England).

\section{Results}

In all patients haematological analyses, liver function tests, thyroid function, and blood biochemistry results were normal. Standard viral screens were also within normal limits (results not shown).

Table 2 shows data pertaining to body mass index, age, and length of illness. In general, the mean Quetelet's Index did not indicate any overt differences from the control patient range (20-25). One patient, however, had a Quetelet's Index of 18.4 (case 10) 
Table 2 Clinical features of patients studied

\begin{tabular}{|c|c|c|c|c|c|c|}
\hline \multirow[b]{2}{*}{ Case No } & \multirow[b]{2}{*}{$\begin{array}{l}\text { Quetelet's } \\
\text { Index }\end{array}$} & \multirow[b]{2}{*}{$\begin{array}{l}\text { Age } \\
(y)\end{array}$} & \multirow{2}{*}{$\begin{array}{l}\text { Length } \\
\text { of history } \\
(y)\end{array}$} & \multicolumn{3}{|c|}{ Antibody reaction against } \\
\hline & & & & VP1 polypeptide & $\begin{array}{l}\text { Coxsackie B } \\
\text { (IgM) }\end{array}$ & $\begin{array}{l}\text { Epstein } \\
\text { Barr Virus }\end{array}$ \\
\hline 1 & $25 \cdot 7$ & 38 & 2 & + & + & - \\
\hline 2 & ND & 30 & 2 & - & - & + \\
\hline 3 & ND & 23 & 4 & - & - & + \\
\hline 4 & ND & 23 & 1 & + & - & - \\
\hline 5 & $20 \cdot 5$ & 23 & 8 & + & - & - \\
\hline 6 & $20 \cdot 1$ & 23 & 7 & - & - & - \\
\hline 7 & ND & 65 & 1 & + & - & - \\
\hline 8 & ND & 40 & 0.5 & + & - & - \\
\hline 9 & ND & 50 & 1 & + & - & - \\
\hline 10 & $18 \cdot 4$ & 37 & 3 & + & - & - \\
\hline 11 & ND & 34 & 17 & + & - & - \\
\hline 12 & ND & 27 & 6 & + & - & - \\
\hline 13 & ND & 50 & 7 & + & - & - \\
\hline 14 & $19 \cdot 3$ & 30 & 10 & + & - & - \\
\hline 15 & ND & 20 & 3 & + & - & - \\
\hline 16 & $24 \cdot 6$ & 29 & 1 & - & - & - \\
\hline 17 & $21 \cdot 5$ & 32 & 7 & + & - & - \\
\hline 18 & $22 \cdot 8$ & 50 & 1 & + & - & - \\
\hline 19 & 19.9 & 40 & 10 & - & - & - \\
\hline 20 & $27 \cdot 3$ & 21 & 3 & + & + & - \\
\hline 21 & ND & 18 & 0.5 & + & - & - \\
\hline 22 & $23 \cdot 4$ & 44 & 3 & + & - & ND \\
\hline 23 & $19 \cdot 7$ & 41 & 8 & + & - & ND \\
\hline $\begin{array}{l}\operatorname{Mean}(\mathrm{SEM}) \\
(\mathrm{n})\end{array}$ & $\begin{array}{l}21 \cdot 9(0 \cdot 8) \\
(12)\end{array}$ & $\begin{array}{l}34(3) \\
(23)\end{array}$ & $\begin{array}{l}4 \cdot 6(0.9) \\
(23)\end{array}$ & $18 / 23$ & $2 / 23$ & $2 / 20$ \\
\hline
\end{tabular}

Patients were diagnosed as having PVFs on the basis of their clinical histories. The normally accepted range of the Quetelet's Index is 20-25. Plasma was tested for IgM antibody (Coxsackie B $1 \mathrm{gM}$ ) and viral antigen for Epstein-Barr virus. + and - signs indicate positive and negative reactions, respectively. ND $=$ not determined.
Table 3 Whole-body potassium and plasma enzyme activities in PVFS

\begin{tabular}{llll}
\hline $\begin{array}{l}\text { Case } \\
\text { number }\end{array}$ & $\begin{array}{l}\text { Total body } \\
\text { potassium (\%) }\end{array}$ & $\begin{array}{l}\text { Plasma } \\
\text { carnosinase }\end{array}$ & $\begin{array}{l}\text { Plasma } \\
\text { creatine } \text { kinase }\end{array}$ \\
\hline 1 & 105 & 190 & 88 \\
3 & ND & ND & 54 \\
5 & ND & ND & 41 \\
8 & ND & ND & 42 \\
9 & ND & ND & 40 \\
10 & ND & 85 & 43 \\
14 & 105 & 132 & ND \\
16 & ND & ND & 41 \\
17 & ND & ND & 91 \\
19 & 100 & 159 & 27 \\
20 & ND & ND & 78 \\
22 & 98 & 130 & 166 \\
23 & 85 & 100 & 87 \\
Mean & & $133(16)$ & $67(11)$ \\
(SEM) & $99(4)$ & & \\
Normal & & $100-200$ & $20-205$ \\
range & $95-105$ & & \\
\hline
\end{tabular}

\begin{abstract}
Data are shown as the mean (SEM) of samples taken from 20 patients or 22 controls. Significance for the RNA composition was assessed by Student's $t$ test as data were normally distributed and variances were equal. The data for the protein composition were not normally distributed and the Wilcoxon rank sum test was used.
\end{abstract}
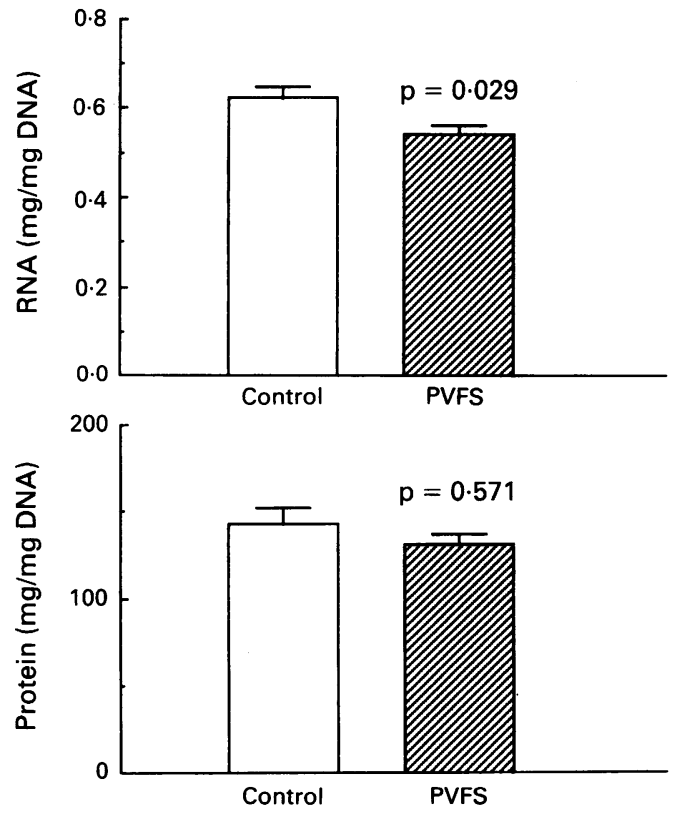

PVFS: Post viral fatigue syndrome but she did not have any histological abnormalities in either type I or II fibres. Nevertheless, this patient did have a low plasma carnosinase activity. The data in table 2 show that 18 patients $(80 \%)$ were positive when tested against the VP1 antigen polypeptide and two $(10 \%)$ were also positive for enterovirus IgM. A separate $10 \%$ of patients had positive indications of Epstein-Barr virus reactivation (table 2 ).

In all 23 patients light microscopic examination of sections of the muscle biopsy specimens showed that most of the muscle fibres were of normal appearance. Two cases showed occasional split fibres and these were the two cases which had the highest atrophy factors. Two further cases showed a modest amount of centronuclear chains but were normal on histomorphometric analysis. There was no evidence of fibre necrosis, phagocytosis, or of any inflammatory infiltrate in any of the biopsy specimens. Histomorphometric analysis indicated eight patients with atrophy or hypertrophy factors outside the normal range (table 1). These were three patients with hypertrophy of both type I and type II fibres, one patient with hypertrophy of just type I fibres, one patient with hypertrophy of type II fibres and three patients with atrophy of type II fibres (table 1). It must be emphasised that these were needle biopsy specimens and so, inevitably, are subject to some artefact. A biopsy specimen from case 15, which had the highest hypertrophy factor, appeared particularly disrupted and this may well have produced artefactually large fibres. It is also recognised that some fibres in a needle biopsy specimen may undergo hypercontraction before freezing, and so the samples showing mildly increased hypertrophy factors were probably normal.

Table 3 shows that whole-body potassium values in the five patients studied were within the control range. In general, plasma carnosinase and creatine kinase activities were also within the normal ranges, but one patient had a slightly reduced carnosinase activity.

The figure shows that RNA concentrations were reduced in patients with PVFS, by about $15 \%$, though the concomitant decrease in protein:DNA did not reach significance.

\section{Discussion}

The pathogenetic mechanisms responsible for the disorder commonly known as post-viral fatigue syndrome or myalgic encephalomyelitis are unknown. A metabolic disorder of muscle caused by persistent viral infection has been suggested. ${ }^{2321}$ In one study $46 \%$ of patients and $25 \%$ of controls had IgM antibodies to Coxsackie B virus, though in this study only $10 \%$ of patients had Coxsackie B IgM antibodies. ${ }^{21}$ Nevertheless, $80 \%$ of patients had serological indications of current or ongoing (VP1 positive) enterovirus infection. A positive VP1 antibody titre is a measure of enterovirus group specific antigen, which is both free and complexed. There has to be a persistent enterovirus infection to pro- 
duce the response; it does not rely on the body's development of antibody. Other recent studies, using molecular biology techniques, have also shown enteroviral RNA sequences in significant numbers of patients with PVFS. ${ }^{22-24}$ How a persistent viral infection might mediate the disorder has not been fully explained, though various theories have been forwarded. ${ }^{25}$ Such persistent infections might interfere with the balance of protein synthesis and degradation, as has been shown to occur in acute sepsis. ${ }^{26}$ This would imply that PVFS is characterised by a generalised reduction in the relative amount of skeletal muscle protein, to account for the muscle weakness. In general, however, neither the Quetelet's Index, whole-body potassium (a direct estimate of muscle mass), nor plasma carnosinase activities (an indirect estimate of muscle mass) were changed in patients with PVFS.

It is therefore necessary to speculate whether groups of proteins, such as those pertaining to the contractile apparatus (the myofibrillary proteins), are reduced in PVFS. Although there is no evidence to support this suggestion, there was a small reduction in the protein:DNA ratio in patients with PVFS. Furthermore, skeletal muscle RNA was significantly reduced. This reflects a reduced capacity or potential to synthesis proteins. ${ }^{27}$ Disturbed protein turnover has indeed been shown by Pacy et al. ${ }^{28}$ Using primed constant infusions of $\mathrm{L}-\left[1-1^{13} \mathrm{C}\right]$ leucine they showed that fractional rates of skeletal muscle protein synthesis were significantly reduced in patients with PVFS. ${ }^{28}$ By implication, muscle protein breakdown may also be reduced to account for the maintenance of the tissue protein content.

Histochemical studies by Byrne et al showed striking type II fibre atrophy. ${ }^{4}$ Their investigations, however, were carried out in only two patients. Our data showed that only three of 23 patients had relatively mild type II fibre atrophy and these were considered to have managed their disease poorly. The study of Byrne and our results together imply that there is a subgroup of patients with PVFS in which symptoms of skeletal muscle weakness may be related to proximal myopathy. In this regard more detailed investigative studies have been made into muscle strength, such as endurance and fatigability. Lloyd et al examined a relatively large patient population ( 20 controls and 20 patients) and determined that, while maximal isometric strength was not affected by the disease process, there was a noticeable inhibition recovery from the peak torque after endurance exercise. ${ }^{29}$ These authors concluded that the contrasting data of subjective muscle weakness and objective state of normal muscle function may have been due to altered patient perception of achieved force and exertion. ${ }^{29}$ The disease definitions of their patients were, however, different from ours. To a certain extent, these conclusions, are similar to those of Stokes et al who studied patients with effort syndrome. ${ }^{30}$ Not all their patients had histories of viral infections before the onset of symptoms. It is appropriate to speculate whether numerous reports in this field do, in fact, examine heterogeneous groups of patients. And there is a fundamental need for a concise and universally accepted medical definition of PVFS. $^{31}$

More recently, direct evidence has been obtained for a subcellular metabolic defect in the muscle per se. ${ }^{32}$ These studies indicate that up to $80 \%$ of patients with PVFS have indentifiable mitochondrial abnormalities. ${ }^{32}$ Thus deficiencies in energy generation may in some way be related to defects in the turnover of muscle RNA or proteins, which are energy dependent processes. ${ }^{27}$ Alternatively, inactivity, or lack of exercise may be precipitating factors for perturbations in protein metabolism in these patients.

We are extremely grateful to Professor Mowbray for the serological analyses.

1 Smith DG. Myalgic encephalomyelitis. (The Royal College of General Practitioners Members' Reference Book. London: Sabrecrow Publishing, 1989:247-50.

2 Archer MI. The post-viral syndrome: a review. $f R$ Coll Gen Pract 1987;37:212-4.

3 Wessely S, David A, Butler S, Chalder T. Management of chronic (post-viral) fatigue syndrome. $\mathcal{f} R$ Coll Gen Pract 1989;39:26-9.

4 Byrne E, Trounce I, Dennett X. Chronic relapsing myalgia (? post-viral): clinical, histological and biomedical studies. Aust N Z F Med 1985;15:305-8.

5 Behan PO, Behan WMH, Bell EJ. The post-viral fatigue syndrome-an analysis of the findings in 50 cases. $f$ Infect 1985;10:211-22.

6 Jamal GA, Hansen S. Electrophysiological studies in the post-viral fatigue syndrome. $\mathcal{f}$ Neurol Neurosurg post-viral fatigue syndrom

7 Amold DL, Bore PJ, Radda GK, Styles P, Taylor DJ. Excessive intracellular acidosis of skeletal muscle on exercise in a patient with a post-viral exhaustion/fatigue syndrome. Lancet 1984; i: 1367-9.

8 Edwards RHT, Young A, Wiles CM. Needle biopsy for skeletal muscle in the diagnosis of myopathy and the clinical study of muscle function and repair. $N$ Engl $f$ Med 1980;302:261-71.

9 Brookes MH, Engel WK. The histographic analysis of human biopsies with regard to fibre Type I-adult male and female. Neurology 1969;19:221-53.

10 Slavin G, Sowter C, Ward P, Pattoli K. Measurement of skeletal muscle fibre diameters using interactive comskeletal muscle fibre diameters using interactive com-

11 Dubowitz V. Muscle biopsy. A practical approach London: Bailliere Tindall, 1985:93-4.

12 Preedy VR, Peters TJ. The effect of chronic ethanol ingestion on protein metabolism in type I and II fibre-rich skeletal muscles of the rat. Biochem $\mathcal{F}$ 1988;254:631-9.

13 Munro HN, Fleck A. Analysis of tissue and body fluids for nitrogenous constituents. In: Munro $M N$, ed. Mammalian protein metabolism. Vol 3. New York: Academic Press, 1969:423-586.

14 Lowry OH, Rosebrough NR, Fan AL, Randall RJ. Protein measurement with the folin phenol reagent. $\mathcal{f}$ Biol Chem 1951;253:1030-40.

15 Downs TR, Wilfinger WW. Fluorometric quantification of DNA in cells and tissue. Anal Biochem 1983;131: 538-47.

16 Smith IS, Hesp R, Mackenzie J. Total body potassium calibrations for normal and obese subjects in two type of whole-body counter. $\mathcal{F}$ Phys Med Biol 1979;24:171-5.

17 Yousef GE, Bell EJ, Mann GF, Murugesan V, McCartney RA. Chronic enterovirus infection in patients with postviral fatigue syndrome. Lancet 1988; i: 146-50.

18 McCartney RA, Banatvaia JE, Bell EJ. Routine of $\mu$-antibody capture ELISA for the serological diagnosis of coxsackie B virus infections. $f$ Med Virol 1986;19: 205-10.

19 Hotchin NA, Read R, Smith DG, Crawford DH. Active Epstein-Barr virus infection in post-viral fatigue syndrome. F Infect 1989;18:143-50.

20 Duane P, Peters TJ. Serum carnosinase activities in patients with alcoholic chronic skeletal muscle myopa-

21 Calder BD, Warnoc PJ, McCartney RA, Bell EJ Coxsackie $B$ viruses and the post-viral syndrome: a prospective study in general practice. $\mathcal{F} R$ Coll Gen Pract 1987;37:11-4.

22 Gow JW, Behan WMH, Clements GB, Woodall C Riding M, Behan PO. Enteroviral RNA sequences detected by polymerase chain reaction in muscle of 
patients with post-viral fatigue syndrome. $B M 71991$; 302:692-6.

23 Archard LC, Bowles NE, Behan PO, Bell EJ, Doyle D. Post-viral fatigue syndrome: persistence of enterovirus RNA in muscle and elevated creatine kinase. $f R$ Soc Med 1988;81:326-9.

24 Cunningham L, Bowles NE, Lane RJM, Dubowitz V Archard LC. Persistence of enteroviral RNA in chronic fatigue syndrome is associated with the abnormal production of equal amounts of positive and negative strands of enteroviral RNA. $\mathcal{f}$ Gen Virol 1990;71: $1399-402$.

25 Wagenmakers AJM, Coakley JH, Edwards RHT. The metabolic consequences of reduced habitual activities in patients with muscle pain and disease. Ergonomics 1988; 31:1519-27.

26 Baracos V, Rodemann HP, Dinarello CA, Goldberg AL Stimulation of muscle protein degradation and prostaglandin $\mathrm{E}_{2}$ release by leukocytic pyrogen (Interleukin-1). $N$ Engl f Med 1983;308:553-8.
27 Waterlow JC, Millward DJ, Garlick PJ. Protein turnover in mammalian tissues and the whole-body. Amsterdam: mammalian tissues and

28 Pacy PJ, Read M, Peters TJ, Halliday D. Post-absorptive whole-body leucine kinetics and quadriceps muscle protein synthetic rate (MPSR) in the post-viral syndrome. Clin Sci 1988; 75(Suppl 19):36-7.

29 Lloyd AR, Hales JP, Gandevia SC. Muscle strength, endurance and recovery in the post-infection fatigue syndrome. $\mathcal{F}$ Neurol Neurosurg Psychiatry 1988;51: 1316-22.

30 Stokes MJ, Cooper RG, Edwards RHT. Normal muscle strength and fatigability in patients with effort syn-

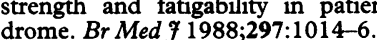

31 Sharpe MC, Archard LC, Banatvala JE. A report-chronic fatigue syndrome: guidelines for research. $\mathfrak{F} R$ Soc Med 1991;84:118-21.

32 Behan WMH, More IAR, Behan PO. Mitochondrial abnormalities in the post-viral fatigue syndrome. Acta Neuropathol 1991;83:61-5. 